\title{
Analisis Semiotika Iklan Produk Elektronik Handphone di Media Cetak
}

\author{
Patrick K.R Linggar \\ Garryn Christian Ranuntu \\ Djeinnie Imbang
}

\begin{abstract}
The objectives of this research are (1) to identify and analyze the types of semiotic meaning of electronic product advertising on magazine including signified and signifier. (2) to analyze whether there is a relationship between the signifier and signified concerning the expression of the meaning that exists in electronic products mobile advertising in the print media; (3) to determine the rhetorical language and why it is used in electronic product advertising. This research is descriptive qualitative study. The data were taken randomly from three magazine monthly editions June and July 2013 as many as 6 product electronic chosen in which the data were taken in various types of mobile electronic product. In identifying and analyzing the semiotic meaning is used semiotic theory concerning (signified and signifier). It can be concluded that semiotic meaning including the use of icon, index, and symbol also types of language are used especially for marketing product. Additionally, further research on semiotic and its elements in magazine or another media may be pursued that the phenomenon of language use and language aspect can be clearly understood.
\end{abstract}

Keywords : semiotic, icon, index and symbol

\section{PENDAHULUAN}

Seperti kita ketahui bahwa bahasa adalah media informasi yang digunakan tiap orang dalam berinteraksi dengan sesamanya. Hal ini disampaikan baik secara lisan maupun tulisan yang mengekspresikan maksud dari tujuan yang diinginkan. Rakhmat (1994) menyatakan bahwa komunikasi verbal adalah bentuk komunikasi yang disampaikan komunikator kepada komunikan dengan cara tertulis atau lisan. Komunikasi verbal menempati porsi besar karena kenyataannya, ide-ide pemikiran atau keputusan lebih mudah disampaikan secara verbal ketimbang non verbal dengan harapan, komunikan (baik pendengar maupun pembaca) bisa lebih mudah memahami pesan-pesan yang disampaikan. Komunikasi verbal melalui lisan dapat dilakukan dengan menggunakan media contohnya seseorang yang bercakap-cakap melalui telepon. Sebaliknya komunikasi verbal melalui tulisan dilakukan dengan cara tidak 
langsung antara komunikator dengan komunikan. Proses penyampaian informasi dilakukan dengan menggunakan media berupa surat, lukisan, gambar, grafik dan lain-lain.

Era globalisasi sekarang ini seperti halnya media informasi baik elektronik maupun cetak yang menampilkan beraneka ragam informasi kepada masyarakatluas menyangkut peristiwa-peristiwa yang dijadikan sebagai sarana simbolis pilihan komunikator atas kumpulan simbol atau peristiwa-peristiwa yang terjadi.Setiapsimbol hadir bersamaan dengan ideologi, dengan demikian pilihan atas seperangkat simbol, sengaja atau tidak merupakan pilihan atas ideologi. Keraf (2001:3-8) menyatakan ada empat fungsi bahasa yaitu: (1) alat untuk menyatakan ekspresi diri; (2) alat komunikasi; (3) alat mengadakan integrasi dan adaptasi sosial; (4) alat kontrol sosial.

Saussure (dalam http://junaedi2008.blogspot.com) menyatakan bahwa semiotik dibagi menjadi dua bagian (dikotomi) yaitu penanda (signifier) dan petanda (signified). Penanda dilihat sebagai bentuk wujud fisik dapat dikenal melalui wujud karya arsitektur sedang petanda dilihat sebagai makna yang terungkap melalui konsep fungsi atau nilai-nlai yang terkandung didalam karya arsitektur. Eksistensi semiotik Saussure adalah relasi antara penanda dan petanda berdasarkan konvensi biasa disebut dengan signifikasi. Semiotik signifikasi adalah sistem tanda yang mempelajari relasi elemen tanda dalam sebuah sistem berdasarkan aturan atau konvensi tertentu.Menurut Saussure, tanda terdiri dari: bunyibunyian dan gambar disebut signifier atau penanda dan konsep-konsep dari bunyi-bunyian dan gambar disebut signified.Dapat dipahami lewat definisi di atas bahwa makna semiotik adalah makna tanda yang dapat dipahami sebagai bahasa yang digunakan orang pada hal-hal tertentu dimaksudkan agar orang terdorong untuk memahami maksud yang ingin disampaikan.

Menurut Williamson (dalam Piliang, 2003:148) “Konsumsi memberikan kesempatan tertentu bagi daya kreativitas seperti sesuatu mainan di mana seluruh bagian-bagiannya telah ditentukan akan tetapi kombinasinya berlipat ganda "Membeli". Tampaklah pemikiran Williamson mengenai adanya kebebasan di balik tindakan konsumsinya.Di sini konsumsi menjadi sebuah fenomena bahasa dan pertandaan yang masuk dalam kawasan semiotik.

Daya visual dan verbal iklan dianggap dapat mengaktifkan citra visual dan memberikan keyakinan verbal sehingga dapat mempengaruhi perasaan dan kepercayaan.Dalam banyak hal makna atau arti suatu pesan disampaikan secara implisit atau 
bersifat konotatif. Dengan demikian makna tadi tidak bisa ditafsirkan sebagai apa yang tampak nyata dalam teks atau secara denotatif.

Produk elektronik seperti handphone yang mengalami perkembangan sangat pesat dewasa ini menampilkan bermacam-macam fitur yang unggul, aplikasi pada handphone yang sekarang ini dikenal dengan smartphone atau ponsel cerdas. Perusahan handphoneberlomba mempromosikan keunggulan produk mereka masing masing melalui iklan entah itu di media cetak ataupun elektronik. Lewat ikon, simbol dan juga indeks citra produk yang diiklankan menjadi hal yang perlu guna tercapainya suatu kesuksesan dalam persaingan bisnis produk yang ditampilkan.

Semiotik (semiotics) berasal dari bahasa Yunani "semeion" yang berarti tanda atau sign. Tanda tersebut menyampaikan suatu informasi sehingga bersifat komunikatif mampu menggantikan suatu yang lain (stand for something else) yang dapat dipikirkan atau dibayangkan(http://bahasa.kompasiana.com)

Zoest (dalam Uniawati 2007:35) semiotikmempelajari sistem-sistem, aturan-aturan, dan konvensi-konvensi yang memungkinkan tanda-tanda tersebut mempunyai arti. Dasar dari semiotik ialah konsep tentang tanda sejauh yang terkait dengan pikiran manusia seluruhnya terdiri atas tanda-tanda sehingga manusia dengan perantaraan tanda-tanda dapat berkomunikasi dengan sesamanya.

Peirce (dalam http://ode87.blogspot.com) menggolongkan semiotik menjadi tiga konsep dasar pertama, semiotik pragmatik yaitu yang menguraikan tentang asal usul tanda, kegunaan tanda oleh yang menggunakannya dan efek tanda bagi yang menginterpretasikannya dalam batas perilaku subjek atau yang mempelajari hubungan antara tanda, pemakai tanda, dan pemakaian tanda. Kedua, semiotik sintaktik yang menguraikan tentang kombinasi tanda tanpa memperhatikan 'makna'nya atau hubungannya dengan perilaku subjek atau secara singkat ialah yang mempelajari hubungan antartanda semiotik ini mengabaikan pengaruh akibat bagi subjek yang menginterpretasikan. Ketiga, semiotik semantik yang menguraikan tentang pengertian suatu tanda sesuai dengan 'arti' yang disampaikan atau dengan kata lain yaitu yang mempelajari hubungan antara tanda, objek, dan interpretannya.

Saussure (dalam http://ode87.blogspot.com) menyatakan bahwa bahasa itu merupakan suatu sistem tanda (sign). Tanda adalah kesatuan dari suatu bentuk penanda 
(signifier) dengan sebuah ide atau petanda (signified). Signifier (penanda) ialah bunyi yang bermakna atau coretan yang bermakna yakni apa yang dikatakan dan apa yang ditulis atau dibaca. Pengaturan makna dari sebuah tanda memerlukan konvensi sosial dikalangan komunitas bahasa di mana makna suatu kata mucul dikarenakan adanya kesepakatan diantara komunitas pengguna bahasa. Sedangkansignified (petanda) ialah gambaran mental yakni pikiran atau konsep (aspek mental dari bahasa). Dengan kata lain pengertian penanda sebagai expression(ungkapan) dan petanda sebagaicontent (isi) diistilahkan juga dengan expression dan content yang satu berwujud bunyi dan yang lain berwujud idea.

Semiotik terdiri dari dua jenis (Hoed 2008 ) yaitu semiotik komunikasi melihat tanda sebagai alat untuk berkomunikasi yang melibatkan pengirim dan penerima tanda. Kedua semiotik signifikasi yaitu memfokuskan perhatian pada produksi tandanya sendiri. Tanda yang digunakan untuk menyampaikan pikiran, informasi dan perintah serta penilaian memungkinkan kita untuk mengembangkan persepsi dan pemahaman terhadap sesama dalam dunia ini.

Sebaliknya, Saussure mengungkapkan bahwa tanda adalah kesatuan dari suatu bentuk penanda (signifier) dengan sebuah ide atau petanda (signified). Penanda ialah bunyi yang bermakna atau coretan yang bermakna yakni apa yang dikatakan dan apa yang ditulis atau dibaca. Pengaturan makna dari sebuah tanda memerlukan konvensi sosial dikalangan komunitas bahasa di mana makna suatu kata mucul dikarenakan adanya kesepakatan diantara komunitas pengguna bahasa.Petanda ialah gambaran mental, pikiran, atau konsep (aspek material dari bahasa).Bahasa sebagai sistem tanda diindikatori oleh adanya hubungan erat antara signifiant, signifie, form, dan substance.

Signifiant yakni gambaran tatanan bunyi secara abstrak dalam kesadaran batin para pemakainya.

Signifie yakni gambaran makna secara abstrak sehubungan dengan adanya kemungkinan hubungan antara abstraksi bunyi dengan dunia luar.

- Form yakni kaidah abstrak yang mengatur hubungan antara butir-butir abstraksi bunyi sehingga memungkinkan digunakan untuk berekspresi.

Substance, yakni perwujudan bunyi ujaran khas 'manusia'.

Ada dua pendekatan terhadap tanda-tanda yang biasanya menjadi ukuran para ahli Sobur (2004:31-35). Pertama, pendekatan yang berdasarkan pada pandangan Saussure yang 
mengatakan bahwa tanda disusun dari dua elemen yaitu aspek citra bunyi (semacam kata atau representasi visual) dan sebuah konsep di mana citra bunyi disandarkan. Kedua, ialah pendekatan yang didasarkan pada pandangan Peirce. Ia menegaskan bahwa tanda-tanda berkaitan dengan objek-objek yang menyerupainya, keberadaannya memiliki hubungan sebab akibat dengan tanda-tanda atau karena ikatan konvensional dengan tanda-tanda tersebut. Ia menggunakan istilah ikon untuk kesamaannya, indeks untuk hubungan sebab akibat, dan simbol untuk asosiasi konvensional.Ketika melihat tanda dari suatu objek, maka kita sama saja mengatribusikan kepada objek itu beberapa signifikansi virtual. Menginterpretasi tanda dalam arti tertentu sama saja dengan mengistimewakan salah satu diantara signifikansi tersebut, dengan menggunakan sesuatu yang sudah kita ketahui. Pengetahuan itu bisa merupakan buah dari pengalaman tentang dunia dan tentang pelbagai hal (http://www.Jalasutra.com).

Ada berbagai tingkatan tanda di dalam semiotik yang memungkinkan untuk dihasilkannya makna yang juga bertingkat-tingkat. Barthes (dalam Piliang, 2004: 94) menjelaskan dua tingkat dalam pertandaan, yaitu denotasi dan konotasi. Denotasi adalah tingkat pertandaan yang menjelaskan hubungan antara penanda dan petanda, atau antara tanda dan rujukannya pada realitas, yang menghasilkan makna yang eksplisit, langsung dan pasti.Tingkatan pertandaan yang paling konvensional di dalam masyarakat yaitu elemenelemen tanda yang maknanya cenderung disepakati secara sosial. Sedangkan konotasi ialah tingkat pertandaan yang menjelaskan hubungan antara penanda dan petanda, yang di dalamnya beroperasi makna yang tidak eksplisit, tidak langsung dan tidak pasti (artinya terbuka terhadap berbagai kemungkinantafsiran).Di dalam gambar atau foto pesan denotasi ialah pesan yang disampaikan oleh gambar secara keseluruhan.Pesan konotasi adalah pesan yang dihasilkan oleh unsur-unsur gambar dalam foto sejauh kita dapat membedakan unsurunsur tersebut.

Iklan biasanya mengandung lambang verbal dan lambang visual yang keduanya saling mengisi (http://id.wikipedia.org/wiki/komunikasi_visual). Komunikasi visual merupakan sebuah rangkaian proses penyampaian kehendak atau maksud tertentu kepada pihak lain dengan menggunakan media penggambaran yang hanya terbaca oleh indera penglihatan. Komunikasi visual mengkombinasikan seni, lambang, tipografi, gambar, desain grafis, ilustrasi dan warna dalam penyampaiannya, sedangkan verbal adalah suatu bentuk 
komunikasi dengan kata-kata baik lisan atautulisan bisa juga menggunakan simbol-simbol verbal.Pengalaman dunia nyata dapat dimanipulasi oleh pengiklan melalui pengasosiasian.Manipulasi ini dimungkinkan dengan menempatkan kata-kata yang disusun dengan cerdik dan penggunaan taktik citra dalam iklan.

Keraf (1992: 3) memberikan pernyataan bahwa retorika adalah suatu cara pemakaian bahasa sebagai seni, baik lisan maupun tertulis yang didasarkan pada suatu pengetahuan yang tersusun baik untuk tujuan mempengaruhi sikap maupun perasaan orang lain. Selanjutnya, Sobur (2004: 84) menyatakan bahwa retorika mempunyai fungsi persuasif dan berhubungan erat dengan pesan yang ingin disampaikan kepada khalayak maka pemakaian gaya bahasa sangat penting sebagai sarana untuk menarik perhatian khalayak dan dapat menonjolkan kebaikan pengirim pesan. Jadi retorika merupakan suatu alat yang dibutuhkan untuk mencapai maksud dan efek yang diinginkan dengan demikian gaya bahasa atau retorika digunakan bukan saja untuk keindahan tapi dapat juga dipakai untuk mengemas argumen untuk menunjukkan kredibilitas pengirim pesan yang terkait dengan maksud sang orator. Keberhasilan persuasi dalam sebuah retorika terkait dengan bagaimana pengirim pesan menyampaikan gagasannya agar menarik perhatian dan pikiran penerimanya.

\section{METODOLOGI PENELITIAN}

Djajasudarma (2006: 16) menyatakan deskripsi merupakan gambaran ciri-ciri data secara akurat sesuai dengan sifat alamiah data itu sendiri.Penelitian ini merupakan penelitian kualitatif, berdasarkan pada data dari penelitian ini yang tidak berupa angka-angka tetapi berupakualitas bentuk verbal dan visual yang berupa teks dan gambar.

Arikunto (1998: 193) menyebutkan bahwa penelitian kualitatif merupakan penelitian deskriptif karena penelitian ini berusaha menggambarkan data dengan kata-kata atau kalimat yang dipisahkan menurut kategori untuk memperoleh simpulan. 
Berdasarkan hal tersebut maka penelitian ini bersifat deskriptif kualitatif karena penelitian ini dimaksudkan untuk memberikan gambaran mengenai tanda-tanda, ikon, indeks, simbol dan bahasa retorika yang terdapat dalam iklan produk elektronik di media cetak

Penelitian ini merupakan penelitian analisis dokumen sehingga dokumen yang berupa surat, artikel, dan editorial diperlukan sebagai bukti pendukung dalam penelitian (Alwasilah, 2002). Objek dalam penelitian ini ialah majalah seperti yang disebutkan di atas.

Di dalam penelitian ini sumber data primer diperoleh dari tiga majalah yaitu T\&t, Forsel dan Droid Magz edisi bulanan kurun waktu Juni dan Juli 2013 dimana datanya diambil secara acak sesuai dengan pilihan peneliti. Ketiga majalah tersebut didapat sepuluh tipe produk yang berbeda dan dipilah- pilah sesuai dengan kriteria yang diperlukan untuk penelitian ini. Sepuluh data yang ada, dipilih enam jenis handphone dengan merek yang sudah dikenal oleh masyarakat luas untuk dianalisis. Keenam data tersebut dianggap mewakili prosedur yang ada. Edisi juni 2013 diambil 1 dari majalah T\&t dan satu dari Forsel. Edisi Juli 2013 diambil empat 1 dari Droid magz 1 dari T\&t dan 2 dari Forsel. Data tersebut dapat digambarkan pada tabel seperti di bawah ini

Tabel 1. Klasifikasi Jenis Data

\begin{tabular}{|c|c|c|c|}
\hline Majalah & T\&t & $\begin{array}{l}\text { Droid } \\
\text { magz }\end{array}$ & Forsel \\
\hline $\begin{array}{lll} & \text { Edisi } & \text { Juni } \\
2013 & & \end{array}$ & 1 & 1 & - \\
\hline $\begin{array}{lll} & \text { Edisi } & \text { Juli } \\
2013 & & \end{array}$ & 1 & 1 & 2 \\
\hline Jumlah & 2 & 2 & 2 \\
\hline
\end{tabular}

Dalam penelitian ini, peneliti menggunakan data-data yang diambil dari dokumen iklan produk elektronik handphone di media cetak seperti yang tersebutkan di atas. Arikunto (1998: 118) menyatakan pengumpulan data dalam kegiatan ini menggunakan teknik pencatatan.Teknik pencatatan dilakukan untuk mencatat kata-kata, kalimat serta gambargambar yang ada dalam iklan produk elektronik edisi Juni dan Juli 2013. Pencatatan di sini 
dimaksudkan agar data-data yang telah terkumpul diklasifikasi berdasarkan rumusan yang ada.

Data yang terkumpul dianalisis dengan tahapan-tahapan sistematis. Berdasarkan tujuan penelitian.

\section{HASIL DAN PEMBAHASAN}

\section{Makna semiotik visual dan verbal}

\section{Iklan handphonePolytron}

Tanda verbal terdiri dari:

Judul

: NOTE CREATIVE STUDIO

Penanda (signifier) : Huruf-huruf "Polytron memang canggih"

Petanda (signified) : Kategori "handphone"

Em-Stylius memungkinkan untuk menulis di layar Wizard Note layaknya menulis di atas kertas. Stylius Gesture memungkinkan untuk melakukan panggilan cepat terhadap aplikasi yang anda inginkan. Long life Baterry dengan kapasitas $2500 \mathrm{MAH}$, lebih tahan lama untuk pemakaian sehari-hari.

Tanda visual terdiri dari:

- $\quad$ Ikon handphone dengan tulisan Polytron

- $\quad$ Super LCD dengan fitur-fitur pelengkap di dalamnya, delapan Mpix AF camera.

- Makna semiotik iklan handphone Polytron dengan judul "Note Creative Studio". Note ditulis lebih besar dengan ukuran tinggi $2 \mathrm{~cm}$ serta ketebalan tulisan $3 \mathrm{~mm}$ yang mana menurut (Hoed, 2004) menyatakan huruf kapital dan ukuran huruf yang besar dalam iklan ini tentu dimaksudkan untuk memperjelas apa yang ingin disampaikan oleh pengiklan yaitu produsen dan juga untuk "mencuri" perhatian dari target yang dituju yang dalam hal ini tentunya calon pelanggan.

"Note creative studio" di mana huruf - huruf "Note" sebagai penanda memberikan pemahaman menulis bukan suatu hal yang tradisional lagi tapi lewat handphone segala sesuatu menjadi lebih mudah, cepat dan efisien. Dan "creative studio" memberikan 
pemahaman bagaimana hal tersebut bisa lebih dieksprsikan menjadi sesuatu yang lebih manarik dengan tampilan yang bisa didesain sesuka hati bisa diganti sesuai suasananya.

"Polytron memang canggih" frasa ini melengkapi apa yang telah dinyatakan sebelumnya sehingga jelas apa yang diinformasikan kepada pembeli bukan hanya mendapatkan handphone sebagai alat komunikasi saja tetapi sebagai media yang mempermudah akses layanan dalam bentuk yang lebih berteknologi yang menampilkan keunggulannya. Di sini kita bisa lihat petanda "handphone" merupakan sebuah alat elektronik yang memiliki screen, battery, penutup belakang dan dilengkapi dengan fitur yang sangat menarik di dalamnya ketika dioprasikan. Huruf - huruf "polytron" yang dalam hal ini sebagai penanda akan menimbulkan konsep yang disebut sebagai petanda. Bisa saja petanda yang timbul berupa kategori handphone dengan tipe dan merek lain. Bagi yang sudah mengenal handphone tipe ini akan sangat mudah mengingat hal yang dimaksud, tetapi berbeda dengan yang tidak mengenal handphone merek ini hanya mendapatkan gambaran umum saja sebagai sebuah ponsel.

Handphone di sini ditampilkan sebagai tanda visual yang mengacu pada gambar yang dipadankan dengan kata "handphone"sehingga memberikan gambaran kepada pembaca sesuai dengan apa yang diketahui mereka sebelumnya. Gambar visual yang terdapat dalam iklan tersebut dimaksudkan agar menjadi pusat perhatian pembaca, yakni menonjolkan "handphone" yang ditawarkan.

Pemasangan gambar handphone ini dimaksudkan untuk memberikan batasan tentang handphone mana yang dimaksud oleh pengirim pesan yaitu tipe handphone yang karakteristiknya sudah disebutkan di atas. Jika kita lihat dari sisi yang lain di mana pengertian yang disebutkan di sini mengacu pada teori konotasi Barthes mengandung arti mana kala handphone juga berfungsi sebagai hard drive yang mampu menyimpan file yang tentu saja sangat berguna bagi pemakainya tentunya disamping sebagai alat komunikasi. Proses selanjutnya akan lebih berkembang seiring dengan pengetahuan yang sudah diperoleh pengguna tentang karakteristik handphone yang dipakai mencakup fitur-fitur kelebihan yang ada pada produk tersebut. Imbas dari hal ini menimbulkan kesan di mana kata kreatif bisa bermakna imaginasi yang bisa digambarkan atau dibuat melalui satu ponsel cerdas.

Penggunaan kata "handphone" menunjuk pada benda yang merupakan alat telekomunikasi yang mana alat ini bisa dioprasikan menggunakan perangkat selular via 
satelit yang bisa menghubungkan pribadi yang satu dengan yang lain walau berbeda jarak, waktu serta tempat. Apabila kita lihat teori Peirce maka akan mendapatkan gambaran "handphone" di sini disebut "representament" yakni terkait dengan objeknya. Handphone merujuk pada alat komunikasi jaringan, gambar handphone merupakan tanda yang adalah gambaran dari bendanya. Kita akan mendapatkan interpretant sebagai satu penafsiran ponsel pintar dengan kemampuan menjelajah lebih cepat dan lebih hemat.

Sebagaimana dinyatakan oleh Peirce di sini, pemaknaan tanda mencakup pengetahuan Individu dalam menafsirkan tanda-tanda tadi. Lingkungan sosial budaya di mana kita hidup sebagai manusia yang saling berinteraksi menghadirkan makna dan kita sebagai penafsir makna tersebut sebagai bagian dari warna hidup yang unik, proses ini akan terus berkembang sesuai dengan siapa penafsirnya. Ada pribadi yang menganggap bahwa memiliki ponsel pintar ialah suatu kebutuhan yang harus dipenuhi seiring dengan perkembangan teknologi dewasa ini tetapi ada pula yang menggunakan handphone sebagai sarana komunikasi saja tanpa harus melihat satu sisi yang mewah dari sebuah handphone. Terkait dengan hal yang sudah disebutkan di atas jika kita melihat perbedaan antara masyarakat perkotaan dan pedesaan tentunya kita mendapatkan jawaban yang berbeda-beda mengenai tanggapan mereka atas hal yang dibicarakan di sini karena mereka melihat ini sebagai suatu kebutuhan yang belum di nomor satukan.

\section{KESIMPULAN DAN SARAN}

Tanda yang ada baik visual atau verbal meliputi hubungan antara penanda dan petanda penggunaan ikon, indeks dan simbol serta bahasa figuratif. Makna tanda baik verbal dan visual yaitu: penanda makna yang disiratkan atau yang dikonvensionalkan berdasarkan kesepakatan makna, petanda konsep pengetahuan individu tentang pelbagai hal. Tanda ialah kesatuan dari bentuk penanda dengan sebuah ide atau petanda. Tanda yang ada memiliki hubungan lewat aturan atau konvensi tertentu semua aspek terkait satu dengan yang lain.

Di dalam membeli produk, yang dalam hal ini tentunya handaphone setidaknya didasarkan pada pengalaman sebelumnya produk mana yang terasa lebih nyaman, pantas dan tidak gampang rusak. Tentunya sebagai tolak ukur dalam membeli sesuatu produk, kita tentunya menginginkan barang dengan kualitas yang berteknologi tinggi dengan fitur-fitur 
mumpuni tapi tentunya tidak gampang rusak juga harganya merakyat. Setiap orang tentunya menginginkan kepuasan terhadapproduk yang mereka beli pastinya. Beranjak dari pada itu, semua tergantung pilihan anda sendiri.

\section{DAFTAR PUSTAKA}

Alwasilah, A. Chaedar. 2002. Dasar-dasar Merancang dan Melakukan Penelitian Kualitatif. Jakarta. Dunia Pustaka Jaya.

Arikunto, S. 1998. Prosedur Penelitian Suatu Pendekatan Praktek. Jakarta: Rhineka Cipta.

Hoed, Benny H. 2008. Semiotik dan Dinamika Sosial Budaya. Jakarta: Komunitas Bambu Jalaludin Rakhmat. 1994. Psikologi Komunikasi. Bandung Remaja Rosdakarya.

Keraf, Gorys. 1992. Diksi dan Retorika. Yokyakarta: PT Kanisius

Piliang, Yasraf A. 2003. Hipersemiotika (Tafsir Cultural Studies Atas Matinya makna) Bandung : Jalasutra.

Sobur, Alex. 2004. Analisis Teks Media. Suatu pengantar untuk Analisis wacana, Analisis semiotik, Analisis Framing. Bandung : PT Remaja Rosdakarya. 